\title{
SHRIMP-EATING FISHES AND A CASE OF PREY-SWITCHING IN AMAZON RIVERS
}

\author{
MICHAEL GOULDING 1 \\ EFREM J. G. FERREIRA 2
}

\section{INTRODUCTION}

There are two families of freshwater shrimp in the Amazon. Palaemonidae contains four genera and 14 species (Kensley and Walker, 1982). Sergestidae is represented by only one genus, and it has two or three species. Over 50 species of Amazonian fishes have been reported to eat shrimp (Tab. 1). To date, however, no Amazon fish species has been identified as a shrimp-eating "specialist". In this paper we report on one catfish and two croaker species which we believe eat shrimp as the main part of their diets, at least in some habitats.

Sorubim lima (Pimelodidae) is a common and widespread catfish in South America, and is known from the Orinoco, Magdalena, Rupununi, Amazon and La Plata drainage systems (Mago Leccia, 1970; Miles, 1947; Eigenmann, 1912; Fowler, 1954; Ringuelet et al., 1967). The most striking features of S. lima are its greatly elongated upper snout that supports rasp-like teeth, its dorsally-ventrally flattened head and its laterally displaced eyes (Fig. 1). Also noteworthy are its long maxillary barbels and stiffened and slightly pungent pectoral and dorsal fin spines. Though coloring varies with water type, S. lima is usually dark dorsally and light ventrally, with a black stripe running horizontally down mid-body. The largest Amazon specimens that we have seen were about $45 \mathrm{~cm}$ in total length. The species is exploited commercially and in subsistence fisheries, though it is not very important in the total Amazon catch (Petrere, 1978; Goulding, 1979, 1981; Smith, 1979, 1981).

The genus Plagioscion (Sciaenidae) is widespread in the freshwaters of South America, and is known from all of the systems cited above for S. lima (also cited by same authors). The genus has not been adequately revised but recent work suggests that there are four Amazonian species (Soares, 1978). Plagioscion squamosissimus and Plagioscion sp. (no published name has yet been given to this species) are abundant in the Central Amazon and they are important food fishes (Petrere, 1978). Croakers of the genus Plagioscion are silvery, elongate fishes with large mouths and eyes (Fig. 2). Their mouths are heavily toothed, 


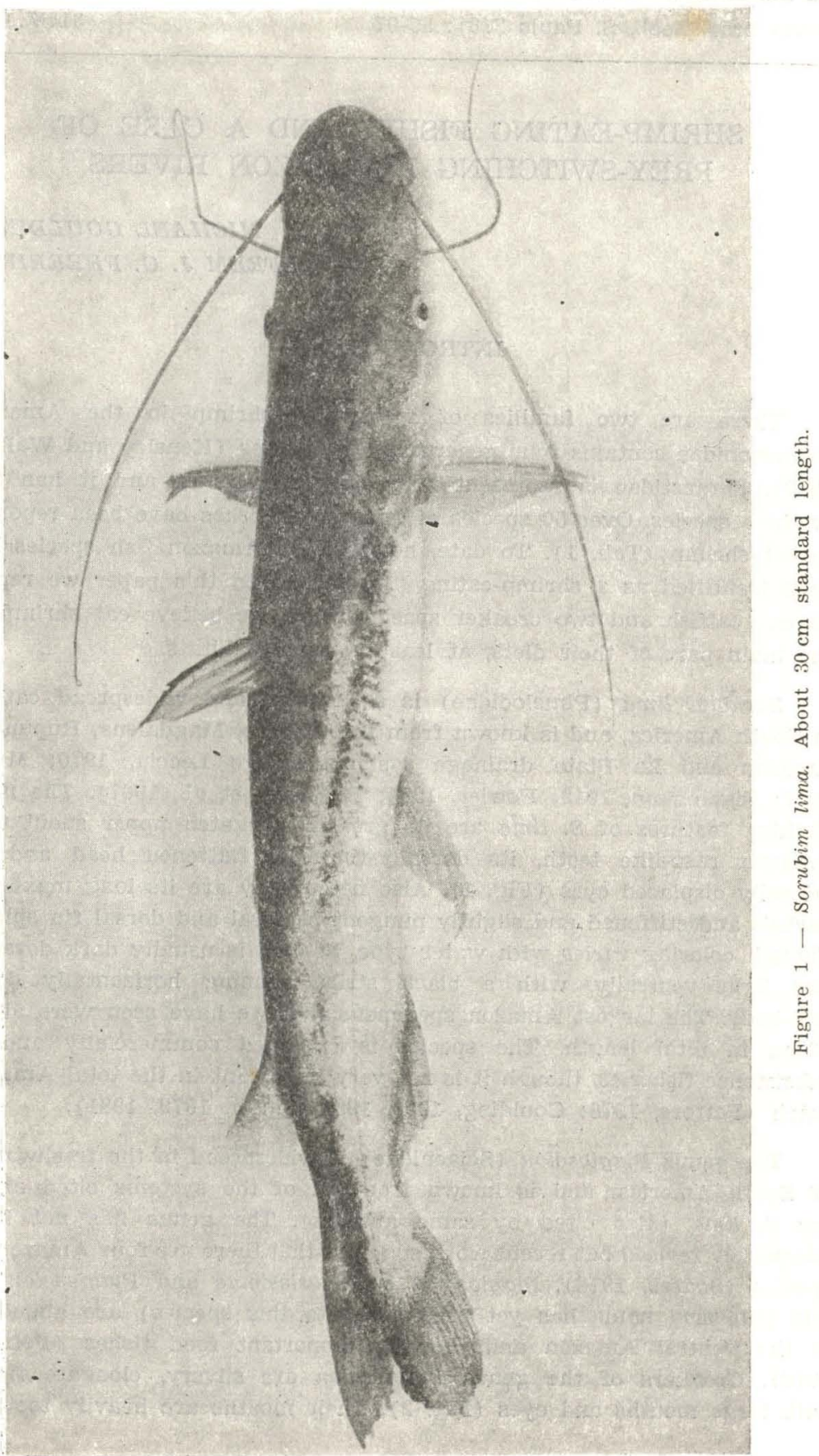




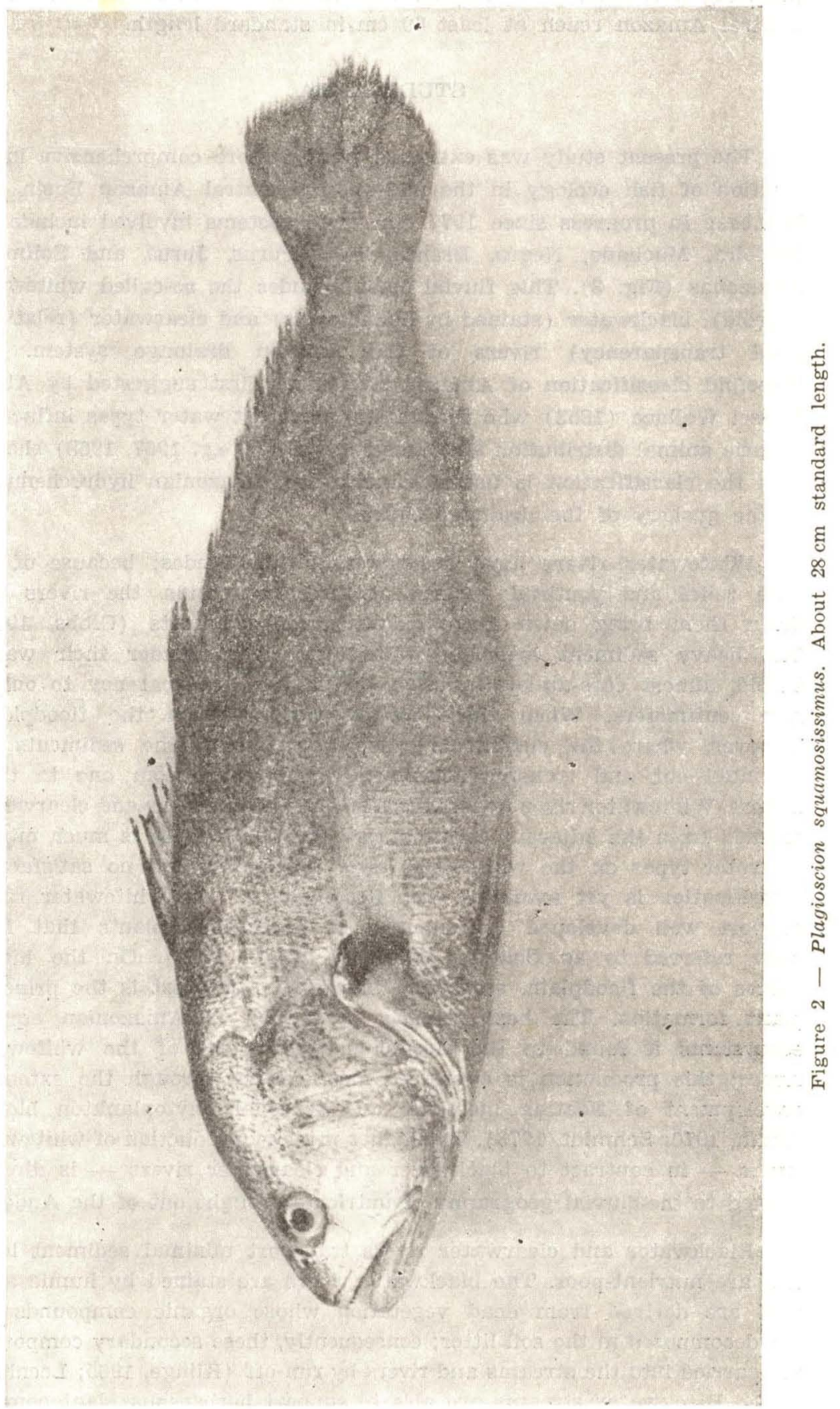


including well developed pharyngeal teeth. The largest Plagioscion of the Central Amazon reach at least $60 \mathrm{~cm}$ in standard length.

\section{STUDY AREA}

The present study was extracted from a more comprehensive investigation of fish ecology in the mid-western/central Amazon Basin that has been in progress since 1977. The river systems involved include the Madeira, Machado, Negro, Branco, Tefé, Purus, Juruá and SolimõesAmazonas (Fig. 3). This fluvial octet includes the so-called whitewater (turbid), blackwater (stained by humic acids) and clearwater (relatively good transparency) rivers of the Amazon drainage system. The threefold classification of Amazon rivers was first suggested by Alfred Russel Wallace (1853) who thought the different water types influenced aquatic animal distribution and abundance. Sioli (e.g. 1967, 1968) showed that the classification is useful for relating Amazonian hydrochemistry to the geology of the drainage basins.

Whitewater rivers have headwaters in the Andes; because of the high relief and youthful geology of these mountains, the rivers that drain them bring down large quantities of sediments (Gibbs, 1967). The heavy sediment loads in whitewater rivers render their waters turbid, almost cafe-au-lait in color, and reduce transparency to only a few centimeters. When these muddy waters reach the floodplains, however, where the current is reduced or absent, the sediments are decanted out and transparencies sometimes reach from one to three meters. Whitewater river floodplains also have blackwaters and clearwaters drained from the adjacent areas; during the floods there is much mixing of water types on the whitewater river floodplains and no satisfactory classification is yet available. The floodplains of the whitewater rivers support well developed communities of herbaceous plants that have been referred to as floating meadows (Junk, 1970). On the higher partes of the floodplain, seasonally inundated rainforest is the principal plant formation. The best primary production in Amazonian aquatic ecosystems is found in the floodplain waterbodies of the whitewater rivers; this production is expressed most clearly through the extensive development of floating meadows and seasonal phytoplankton blooms (Junk, 1970; Schmidt, 1973). The higher primary production of whitewater rivers - in contrast to blackwater and clearwater rivers - is directly related to the fluvial geography of nutrients brought out of the Andes.

Blackwater and clearwater rivers transport minimal sediment loads and are nutrient-poor. The blackwater rivers are stained by humic acids that are derived from dead vegetation whose organic compounds are not decomposed in the soil litter; consequently, these secondary compounds are carried into the streams and rivers by run-off (Klinge, 1965; Leenheer, 1980). Blackwater streams are able to support herbaceous plant communities, but these are low in species diversity and also in biomass compared to the whitewater river areas. Clearwater rivers drain the Brazilian 


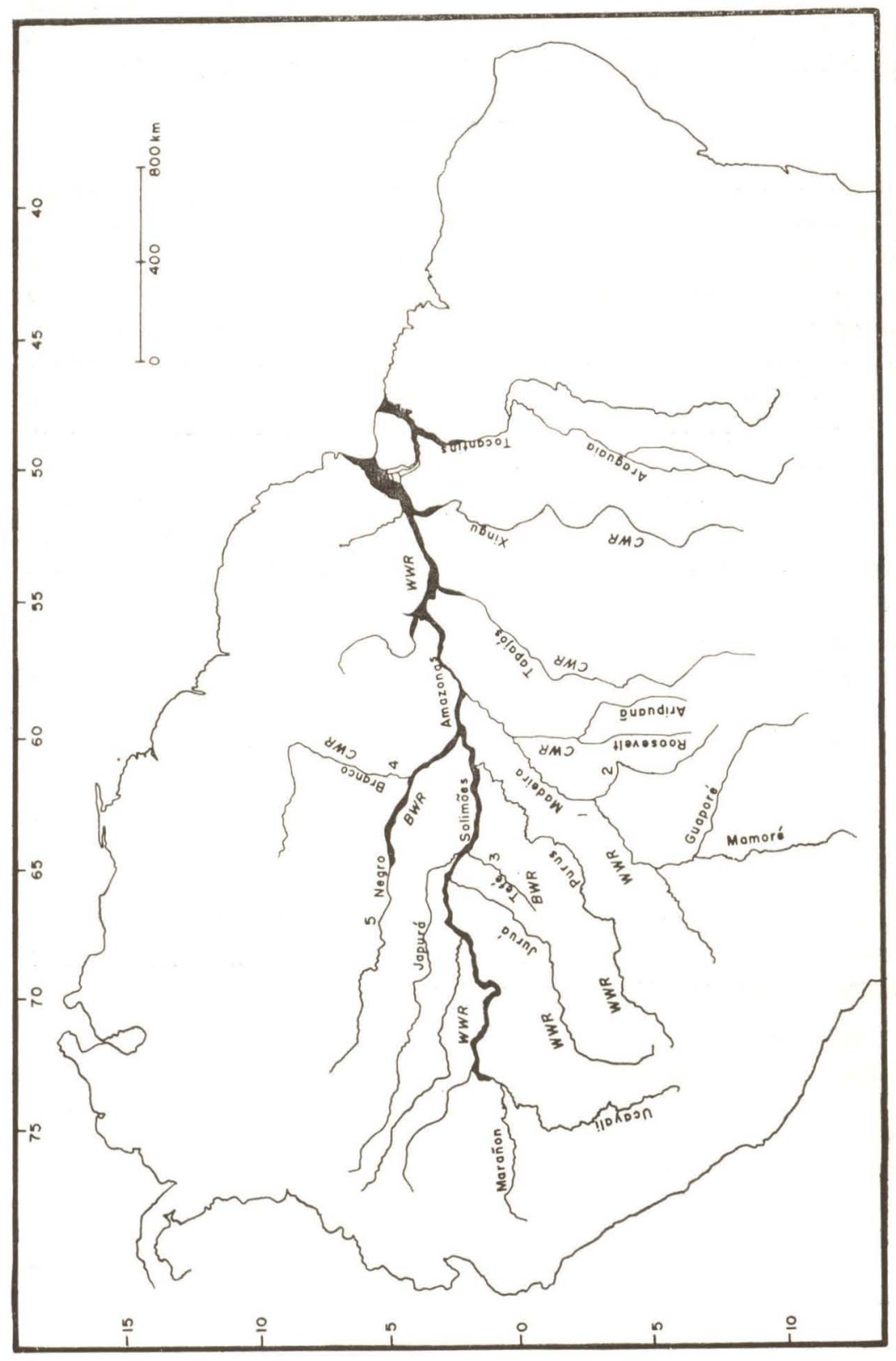

त्] 
and Guiana Shields or areas in the Amazonian Lowlands. They have a wide range of $\mathrm{pH}$ values, though they are usually on the acidic side. Herbaceous plant communities are absent from most clearwater rivers, and intensive plankton blooms have not been reported except in the mouth-lakes of the Tocantins, Xingu and Tapajós (Sioli, 1968).

\section{METHODS}

We have examined the stomach contents of over 100 species of the larger fishes captured in the study area outlined above. The shrimp-eating fishes reported in this paper were discovered while making these analyses. The specimens were captured with gillnets and seines between 1977 and 1980. All of the Sorubim lima specimens reported on are from the Calama floodplain of the upper Rio Madeira (see Fig. 3). These catfishes were captured in floodplain lakes and flooded forests during 1980. Though every month was fished, we only made captures of $\mathbf{S}$. lima during seven months. Because feeding behavior was similar during the low and high water periods, we have combined the results. Plagioscion spp. were captured in eight of the twelve months that the Calama floodplain was investigated; this included both the high and low water periods and, because feeding behavior was similar during both seasons, we combined the results. Plagioscion spp. from the Rio Tefé were captured on beaches during a two week period of August, 1979; this was the beginning of the low water period. The Rio Branco specimens were captured in flooded forests and beaches during a two week period in May, 1979, at which time river level was rising; the results from these two habitats are also combined. Captures of Plagioscion spp. in the Rio Machado were made in 1977 and 1978 and these results have already been reported elsewhere (Goulding, 1980). Shrimp were collected with dipnets and seines and these collections have been identified and incorporated into the most recent and comprehensive taxonomic treatment of Amazonian shrimp (Kensley and Walker, 1982).

The stomach contents of the fishes discussed in this study were analyzed by two methods, namely occurrence and volume. Occurrence was calculated as the number of times that a particular food item was present in the total number of individuals that contained food in their stomachs. Volume was calculated from "fullness" and the relative quantity of each food item. The "fullness" of an idividual's stomach was estimated at the following intervals: 10 percent or less $=1$ point, 25 percent $=2$ points, 50 percent $=3$ points, 75 percent $=4$ points and 100 percent $=5$ points. The individual items were then separated and their contributions estimated as a percentage (10 percent, 25 percent, 50 percent, 75 percent or 100 percent) of the total bulk found in each stomach. The "fullness" points were then multiplied by these relative percentages to determine the importance of individual items in each fish's stomach. Finally, these calculations were summed to determine the relative importance of each item for all of the fishes examined. 
T A B L E 1

Partial list of Amazon and neighboring Guiana fishes that are known to feed on shrimp

$\mathrm{T} \mathbf{A} \times \mathbf{A}$

Potamotrygon cf hystrix (Potamotrygonidae)

Astyanax fasciatus (Characidae)

Astyanax abramis

Byconops caudomaculatus (Characidae)

Charax tectifer (Characidae)

Crytocharax amazonus (Characidae)

Acestrocephalus sardina (Characidae)

Galeocharax gulo (Characidae)

Roeboides spp. (Characidae)

Leporinus friderici (Anostomidae)

Leporinus fasciatus (Anostomidae)

Hoplerythrinus unitaeniatus (Erythrinidae)

Erythrinus erythrinus (Erythrinidae)

Hoplias malabaricus (Erythrinidae)

Rhamdia sp. (Pimelodidae)

Pimelodus clarius (Pimelodidae)

Pimelodus ornatus (Pimelodidae)

Pimelodus blochii (Pimelodidae)

Sorubim lima (Pimelodidae)

Oxydoras niger (Doradidae)

Trachycorystes (Auchenipteridae)

Electrophorous electricus (Electrophoridae)

Gymnotus carapo (Gymnotidae)

Gymnotus anguillaris (Gymnotidae)

Cichla ocellaris (Cichlidae)

Cichla temensis (Cichlidae)

Crenicichla johanna (Cichlidae)

Chenicichla nanus (Cichlidae)

Crenicichla ornata (Cichlidae)

Crenicichla saxatilis (Cichlidae)

Crenicichla lepidota (Cichlidae)

Acaronia nassa (Cichlidae)

Cichlasoma severum (Cichlidae)

Cichlasoma festivum (Cichlidae)

Cichlasoma coryphaenoides (Cichlidae)

Cichlasoma psittacum (Cichlidae)

Cichlasoma bimaculatum (Cichlidae)

Astronotus ocellatus (Cichlidae)

Biotodoma cupido (Cichlidae)

Aequidens duopunctata (Cichlidae)

Aequidens tetramerus (Cichlidae)

Aequidens sp. (Cichlidae)

Geophagus jurupari (Cichlidae)

Geophagus daemon (Cichlidae)

Geophagus surinamensis (Cichlidae)

Plagioscion squamosissimus (Sciaenidae)

Plagioscion spp. (Sciaenidae)

Colomesus ascellus (Tetraodontidae)

Osteoglossum bicirrhosum (Osteoglossidae)

Synbranchus marmoratus (Synbranchidae)
S O U R C E

Saul (1975

Narlier (1968)

Saul (1975)

Saul (1975)

Saul (1975)

Saul (1975)

Pers. obser.

Menezes (1976)

Pers. obser.

Knoppel(1970)

Pers. obser.

Knoppel (1970)

Saul (1975)

Saul (1975)

Knoppel (1970)

Saul (1975)

Saul (1975)

Pers. obser.

Pers. obser.

Goulding (1980)

Pers, obser.

Saul (1975); Pers. obser.

Saul (1975); Knoppel (1970)

Knoppel (1970)

Lowe-McConnell (1969)

Pers, obser.

Knoppel (1970)

Knoppel (1970)

Knoppel (1970)

Lowe-McConnell (1969)

Saul (1975)

Knoppel (1975); Ferreira (1981);

Lowe-McConnell (1969)

Knoppel (1970); Ferreira (1981)

Ferreira (1981)

Ferreira (1981)

Ferreira (1981)

Lowe-McConnell (1969)

Ferreira (1981)

Ferreira (1981)

Ferreira (1981)

Saul (1975)

Saul (1975)

Ferreira (1981)

Ferreira (1981)

Ferreira (1981)

Marlier (1968)

Pers. obser.

Marlier (1968)

Goulding (1980); Aragão (1981)

Pers. obser. 


\section{RESULTS}

Of the 155 specimens $(17-29 \mathrm{~cm}$ Standard Length $=$ SL) of S. lima examined for food contents, 100 individuals had empty stomachs, while the items found in the other 55 included shrimp, cladocerans, copepods, fish and plant remains (Tab. 2). Nearly all of the shrimp were Macrobrachium amazonicum, and no other species could be identified with certainty. In terms of total volume, shrimp accounted for $\mathbf{7 5 . 6}$ percent of the food consumed by S. lima in the Calama floodplain lakes of the Rio Madeira. Fish was the second most important item eaten. Most of these prey appeared to be small characins, but they were too digested to be identified to lower taxonomic levels. The copepod and cladoceran zooplankton were probably ingested accidentally, and the same may be true of the minute quantities of plant remains found.

Of the 46 specimens (15-28 cm SL) of Plagioscion squamosissimus from the Calama floodplain that were examined for stomach contents, only 12 individuals had empty stomachs, while the items found in the other 25 included shrimp, fish and vegetable remains (Tab. 3). Shrimp (mostly $M$. amazonicum) accounted for 97.9 percent of the total bulk of food eaten during the high water period and 66.5 percent during the low water season. The only other item of any importance was fish. Only 13 Plagioscion sp. (17-30 cm SL) specimens were examined because so few were captured. During the high and low water periods shrimp was by far the most important item eaten (Tab. 3).

Of the 11 specimens (18-43 cm SL) of P. squamosissimus examined from the Rio Tefé, only four contained food in their stomachs; two of these had eaten fish (Hoplias malabaricus, Chilodus punctatus and Acestrorhynchus sp.) while the remaining pair contained shrimp that could not be identified to species because they were already largely digested. Only three specimens (26-36 cm SL) of Plagioscion sp. nov. from the Rio Tefé were examined, one of which was empty, one contained a Curimata sp. fish and the last had eaten macrophyte roots.

Only four specimens (18-29 $\mathrm{cm}$ SL) of $P$. squamosissimus from the Rio Negro were examined for stomach contents. Two were empty and two contained fish.

Of the 28 specimens (16-37 cm SL) of $P$. squamosissimus captured on beaches and in flooded forest of the lower Rio Branco, 14 individuals had eaten fish; no other food item was found. Fish prey included gymnotoids, Curimata spp., and small loricariid catfishes.

The feeding behavior of $P$. squamosissimus from the Rio Machado has already been reported, though Plagioscion sp. was not recognized at the time (Goulding, 1980). Of the 217 Rio Machado specimens (22-48 cm SL) examined, from both floodplain lakes and flooded forests, 85 individuals contained food in their stomachs. The only food item found was fish, and these included Anodus, curimatids, Serrassalmus, Triportheus, loricariids and small pimelodids. 


\section{TABLE 2}

Stomach content analyses of Sorubim lima from the Calama floodplain of the Rio Madeira.

\begin{tabular}{|l|c|c|c|c|}
\hline \multirow{2}{*}{ FOOD ITEM } & \multicolumn{2}{|c|}{ OCCURRENCE } & \multicolumn{2}{c|}{ V O L U M E } \\
\cline { 2 - 5 } & $N^{\varphi}$ & $\%$ & Total & $\%$ \\
\hline Shrimp & 41 & 74.5 & 18.840 & 75.6 \\
Fish & 10 & 18.2 & 4.625 & 18.6 \\
Plant remains & 7 & 12.7 & 695 & $\mathbf{2 . 8}$ \\
Cladocera & 2 & 3.6 & 480 & 1.9 \\
Copepoda & 1 & 1.8 & 120 & 0.5 \\
Unidentifiable & 1 & 1.8 & 140 & 0.6 \\
\hline
\end{tabular}

\section{TABLE 3}

Stomach content analyses of Plagioscion from the Calama floodplain of the Rio Madeira.

Plagioscion squamosissimus

\begin{tabular}{|l|r|r|r|r|}
\hline \multirow{2}{*}{ FOOD ITEM } & \multicolumn{2}{|c|}{ OCCURRENCE } & \multicolumn{2}{c|}{ V O L U M E } \\
\cline { 2 - 5 } & $N^{\circ}$ & $\%$ & Total & $\%$ \\
\hline Shrimp & 30 & 94 & 11.130 & 91 \\
Fish & 4 & 12 & 790 & 06 \\
Plant remains & 2 & 06 & 210 & 02 \\
Unidentifiable & 1 & 03 & 70 & 01 \\
\hline
\end{tabular}

Plagioscion sp.

\begin{tabular}{|l|r|r|r|r|}
\hline Shrimp & 9 & 90 & 1.800 & 78.3 \\
Fish & 1 & 10 & 500 & 21.7 \\
\hline
\end{tabular}




\section{DISCUSSION}

Obvious morphological adaptations for shrimp-eating appear to be very rare in Amazon fishes. We hypothesize that there are two principal reasons for this. Firt, the shrimp biomass of the Amazon river system appears to be relatively low, at least compared to fish. Though no quantitative information exists, we can strongly suggest, from much personal observation, that the Amazon shrimp biomass, except in the estuarine area, is too low to support commercial operations of any scale. Likewise, we believe that the Amazon shrimp biomass is too low to support but a few fish species that specialize on it as their main food. Second, the size of the shrimp, compared to their piscine predators, and the crustacean's soft carapaces, present few problems for ingestion by fishes. In general we believe that the major ecological characteristics of Amazonian shrimp-eating fishes are to be sought more in predatory behavior - which is beyond the purview of the present study - than in morphology. Here we can offer only one exception to this generalization.

The greatly elongated upper jaw of Sorubim lima is undoubtedly an adaptation for imprisoning prey against a substrate, a prenomenon that has been observed by the second author in aquaria. Our study suggests that shrimp is the main prey of S. lima in whitewater floodplain lakes of the Amazon, and we believe that it is captured mostly on the bottom. If, in fact, the elongated upper jaw of S. lima is a specialized morphological adaptation for capturing shrimp, then these crustaceans should be the principal item in the catfish's diet over its wide area of distribution. Only further studies from other systems can test this hypothesis.

Our gillnet and seine samples reveal that $\mathbf{S}$. lima is only abundant in the whitewater river habitats in the mid-western/central Amazon. Only a few specimens were captured in blackwater and clearwater rivers. Fisheries data also indicate that S. lima is found mostly in the whitewater rivers (Petrere, 1978; Goulding, 1979, 1981). We hypothesize that the relative abundance of S. lima in Amazonian waters is correlated with shrimp abundance. Unfortunately, we do not have enough specimens from blackwater and clearwater rivers to determine whether S. lima feeds principally on shrimp in these systems, or alternatively, switches prey, which would then most likely be small fishes. It should also be noted that Macrobrachium amazonicum, the most important shrimp species eaten by the fishes reported herein, is either absent or very rare in the blackwater and clearwater rivers of the Central Amazon. The shrimp biomass in blackwater and clearwater rivers is also much lower than that encountered in whitewater river systems, though no quantitative data are yet available on these differences. The shrimp in the nutrient-poor rivers also appear to be much smaller (Pers. obser. and Kensley and Walker, 1982).

In the clearwater Rio Machado croakers were one of the two most abundant predatory taxa captured (Goulding, 1980). Our data clearly 
reveal that croakers living in blackwater and clearwater rivers feed mostly on fish in contrast to those populations inhabiting whitewater rivers that eat mostly shrimp. We hypothesize that the croakers in blackwater and clearwater rivers must eat fish for a lack of shrimp. The question that then arises is why do the croakers prefer shrimp over fish in the whitewater river floodplain areas? Three hypotheses suggest themselves. First, that shrimp is easier for them to capture in the whitewater floodplain areas. Second, that shrimp is more nutritious in croakers' diets than fish. Third, that whitewater river floodlpain habitats have competitive piscivorous predators that are missing from the blackwater and clearwater rivers. The first two hypotheses are testable and may be of eventual interest to fish culturalists. Here we will only offer insights on the third hypothesis, which is the least testable.

Fisheries data and our own experimental gillnet and seine captures show that the most abundant predators in Amazonian whitewater river floodplain waterbodies are Cichla spp., Serrasalmus spp. and Plagioscion spp. (Petrere, 1978; Goulding, 1979, 1981). Species of Cichla and Plagioscion are abundant in all river types that we have investigated, whereas the most piscivorous whitewater river piranha (S. nattereri) is missing, or very rare, in the blackwater and clearwater rivers. In the Rio Madeira study site we captured about 3,000 S. nattereri (mostly adults) in contrast to 75 individuals of Plagioscion spp. in a year of fishing. Blackwater and clearwater rivers that we have investigated have no comparable predator to $S$. nattereri (not even another piranha species). It is thus possible that Plagioscion spp. are able to maintain relatively large biomasses in the blackwater and clearwater rivers because they are able to switch from shrimp to fish in the absence of a dominant predator like S. nattereri.

\section{CONCLUSION}

Sorubim lima and Plagioscion squamosissimus and Plagioscion sp. are the only known Amazon fish taxa that, at least in some areas, eat shrimp as the major part of their diets. The shrimp-eating catfish and croakers are so different morphologically that it would be difficult to guess that their feeding behavior converged on the exploitation of shrimp, and especially Macrobrachium amazonicum. Further studies should be able to elucidate the behavioral adaptations that catfish and croakers, among a long list of other predators, have for capturing shrimp diurnally and nocturnally. Likewise, the shrimp must have adaptations for avoiding their diverse predators.

The croakers reported herein are the first Amazonian predatory fishes whose diets are known to be influenced by water type. Too little is yet known about the Amazon fish fauna to determine whether this is an aberrant case, or a phenomenon that, as we suspect, will also be found in other groups. This study suggests that when an Amazonian 
fish species is known to inhabit more than one water type, then its diet, in an ecological sense, can only be understood by investigating feeding behavior in all of the water types involved.

\section{REFERENCES}

Aragão, L. P., 1980. Desenvolvimento embrionário $e$ larval, alimentą̧ão $e$ reprodução do araunã, Osteoglossum bicirrhosum Vandelli 1829, do Lago Janauacá - Amazonas, Brasil. Master's Thesis, Instituto Nacional de Pesquisa da Amazônia (INPA), Manaus.

Eigenmann, C. H., 1912. The freshwater fishes of British Guiana, including a study of ecological grouping of species. Mem. Carnegie Mus. 5: 1-158.

Ferreira, E. J. G., 1981. Alimentação dos adultos de doze espécies de ciclideos (Perciformes, Cichlidae) do Rio Negro, Brasil. Master's Thesis, Instituto Nacional de Pesquisa da Amazônia (INPA), Manaus.

Fowler, H. W., 1954. Os peixes de água doce do Brasil. Archos Zool. Est. S. Paulo 9: 1-400.

Gibbs, R. J., 1967. The geochemistry of the Amazon river systems: Part I. The factors that control the salinity and the composition of the suspended solids. Bull. Geol. Soc. Am. 78: 1203-1232.

Goulding, M., 1979. Ecologia da Pesca do Rio Madeira. Conselho Nacional de Desenvolvimento Científico e Tecnológico e Instituto Nacional de Pesquisas da Amazônia, Manaus.

Goulding. M., 1980. The Fishes and the Forest: Explorations in Amazonian Natural History. University of California Press, Berkeley and Los Angeles.

Goulding. M., 1981. Man and Fisheries on an Amazon Frontier. Junk Publishers, The Hague.

Junk, W., 1970. Investigations on the ecology and production-biology of the 'floating meadows' (Paspalo-Echinochloetum) on the Middle Amazon. Part. I. The floating vegetation and its ecology. Amazoniana 2 (4): 449-495.

Kensley, B. \& Walker, I., 1982. Palaemonid shrimps from the Amazon Basin, Brazil. Smithson. Contr. Zool.

Klinge, H., 1965. Podzol soils in the Amazon Basin. J. Soil Sci. 16: 95-193.

Knoppel, H. A., 1970. Food of Central Amazonian fishes: contribution to the nutrient-ecology of Amazonian rain-forest streams. Amazoniana 2: 257-352.

Leenheer, J. A., 1980. Origin and nature of humic substances in the waters of the Amazon river basin. Acta Amazonica 10 (3): 513-526.

Lowe-McConnell, R. H., 1969. The cichlid fishes of Guyana, South America, with notes on their ecology and breeding behaviour. Zool. J. Linn. Soc. 48: 255-302.

Mago Laccia, F., 1970. Lista de los peces de Venezuela. Ministerio de Agricultura y Oficina Nacional de Pesca, Caracas, Venezuela.

Marlier, G., 1968. Etudes sur les lacs de l'Amazonie centrale. III. Les poissons du lac Redondo et leur regime alimentaire; les chaines tropiques du lac Redondo; les poissons du rio Preto ảa Eva. Caderno da Amazônia 23-57.

Menezes, N. A., 1976. On the Cynopotaminae, a new subfamily of Characidae (Osteichthyes, Ostariophysi, Characoidei). Arq. Zool. S. Paulo 28 (2): 1-91.

Miles, C., 1947. Los peces del Río Magdalena. Ministério de la Economia Nacional, Bogotá.

Petrere, M., 1978. Pesca e esforço de pesca no Estado do Amazonas. II. Locais, aparelhos de captura e estatísticas de desembarque. Acta Amazonica 8 (3, Supl. 2): $54 \mathrm{p}$. 
Ringuelet, R. A., Aramburu, R. H. \& Aramburu, A. A. 1967 . Los peces argentinos de agua dulce. Comision de Investigacion Cientifica, La Plata.

Saul, W. G., 1975. A study of fishes at a site in upper Amazonian Ecuador. Proc. Acad. nat. Sci. Philadelphia 127: 93-134.

Schmidt, G. W., 1973. Primary production of phytoplankton in the three types of Amazonian waters. Amazoniana 4 (2): 135-138.

Sioli, H., 1967. Studies in Amazonian waters. Atas do Simpósio sobre a Biota Amazonica 3: 9-50.

Sioli, H., 1968. Hydrochemistry and geology in the Brazilian Amazon region. Amazoniana 1 (3): 267-277.

Smith, N. J. H., 1979. A pesca no rio Amazonas. Conselho Nacional de Desenvolvimento Científico e Tecnológico e Instituto Nacional de Pesquisas da Amazônia, Manaus.

Smith, N. J. H., 1981. Man, Fishes, and the Amazon. Columbia University Press, New York.

Soares, L. H., 1978. Revisão taxonômica dos sciaenideos de água doce da região amazônica brasileira (Osteichthyes, Perciformes, Sciaenidae). Master's Thesis, Instituto Nacional de Pesquisas da Amazônia (INPA), Manaus.

Wallace, A. R., 1853. A Narrative of Travels on the Amazon and Rio Negro. Reeves, London. 